\title{
DA CELEBRAÇÃO À COMOÇÃO: OS DISCURSOS DA IMPRENSA ESCRITA PAULISTA EM RELAÇÃO A UMA CÉLEBRE LUTA DE BOXE ${ }^{1}$
}

\author{
From The Celebration to the Commotion: The Discourse of the Paulist \\ Press in Relation to a Celebrated Boxing Fight
}

Riqueldi Straub Lise $^{2}$
Fernando Renato Cavichiolli
André Mendes Capraro

\begin{abstract}
RESUMO
O objetivo deste estudo consiste em explicitar as mudanças nos discursos da imprensa escrita paulista, acerca da capacidade pugilística de Benedicto dos Santos no confronto que realizou contra o campeão europeu dos pesos pesados de boxe, Ermínio Spalla. Tendo como fontes primárias os jornais da cidade de São Paulo, foi adotado os preceitos metodológicos preconizados por Luca (2011) para a análise das referidas fontes. Notou-se ao longo desse estudo, que a partir da confirmação do confronto de boxe entre dos Santos e Spalla a imprensa paulista noticiou amplamente vários aspectos relacionados ao evento. Um desses aspectos faz menção a capacidade física e técnica do pugilista brasileiro de enfrentar um lutador muito experiente e aprimorado tecnicamente. Se em um primeiro momento, a imprensa escrita, considerava dos Santos inapto para tal desafio, em um segundo momento admitia que o lutador brasileiro possuía reais chances de obter a vitória sobre o contendor italiano, e por fim, ao noticiar a hospitalização de dos Santos, em decorrência dos golpes de Spalla, percebe-se outra mudança nos discursos, a de que esta luta nunca deveria ter acontecido devido a diferença física e técnica entre os dois lutadores.
\end{abstract}

Palavras-chave: Periódicos; Discurso; Boxe.

1 Esta pesquisa contou com o apoio financeiro da Coordenação de Aperfeiçoamento de Pessoal de Nível Superior (CAPES).

2 Graduação em Educação Física pela Universidade Positivo, Mestrado e Doutorado Universidade Federal do Paraná. E-mail: liseriqueldi@gmail.com. ORCID: https://orcid.org/0000-0001-7565-4816.

3 Graduação, Mestrado e Doutorado em Educação Física, Professor titular da Universidade Federal do Paraná. E-mail: cavicca@hotmail.com. ORCID: https://orcid.org/0000-0001-8925-2420.

4 Graduação em Educação Física, Mestrado e Doutorado em História pela Universidade Federal do Paraná. Professor do Departamento de Educação Física da Universidade Federal do Paraná. E-mail: andrecapraro@onda.com.br. ORCID: https:// orcid.org/0000-0003-3496-3131. 


\begin{abstract}
The objective of this study is to explain the changes in the speeches of the São Paulo press, about the pugilistic capacity of Benedicto dos Santos in the confrontation he had against the European heavyweight boxing champion, Ermínio Spalla. Having as primary sources the newspapers of the city of São Paulo, the methodological precepts recommended by Luca (2011) were adopted for the analysis of these sources. It was noted throughout this study, that from the confirmation of the boxing confrontation between dos Santos and Spalla, the São Paulo impensa reported widely several aspects related to this fight. One of these aspects mentions the physical and technical capacity of the Brazilian boxer to face a very experienced and technically improved fighter. If, at first, the written press considered dos Santos unfit for such a challenge, in a second moment he admitted that the Brazilian fighter had real chances of obtaining victory over the Italian contender, and finally, when reporting the hospitalization of dos Santos, as a result of Spalla's blows, there is another change in the speeches, that this fight should never have happened due to the physical and technical difference between the two fighters.
\end{abstract}

Keywords: newspaper; discourse; boxing.

\title{
Introdução
}

Aos 27 dias do mês de janeiro de 1924, fazia escala no porto da cidade do Rio de Janeiro, rumo a Buenos Aires, o transatlântico francês Lutetia. Entre os passageiros a bordo deste navio estava o célebre pugilista italiano Erminio Spalla5. Nesta ocasião o jornal Correio Paulistano, primeiro jornal diário de São Paulo e com vendagem significativa, publicou uma breve entrevista, na qual Spalla discorre acerca de sua vinda à América do Sul, cujo principal compromisso era a luta contra o argentino Luiz Angel Firpo6. Spalla declarou que, no retorno de Buenos Aires, desejava realizar, na cidade de São Paulo, um confronto contra o pugilista brasileiro Benedicto dos Santos, também conhecido como Ditão (CORREIO PAULISTANO, 1924).

Assim o objetivo deste estudo está centrado em descrever como os periódicos brasileiros ${ }^{7}$ noticiaram a passagem de Erminio Spalla pelo Brasil, com atenção especial à luta que realizou contra o pugilista Benedicto dos Santos no ano de 1924, em São Paulo. Para tanto, foram consultados os jornais da cidade paulistana, e ainda, com sentido de ampliar a escala de análise e constatar a repercussão desta luta fora de São Paulo, também foram incluídos periódicos da cidade do Rio de Janeiro, naquela época capital federal e cidade com maior contingente populacional do Brasil.

A escolha de matérias jornalísticas como fontes primárias para esta pesquisa se deu,

5 Alguns periódicos cariocas afirmam que Spalla veio da Itália a bordo do Paquete Pincio.

6 O argentino Luiz Angel Firpo era, desde 1920, campeão sul-americano dos pesos pesados e em 1923 foi o primeiro pugilista da América do Sul a disputar o título mundial contra o então campeão mundial Jack Dempsey. Esta luta, realizada em Nova Iorque, terminou com a polêmica vitória de Dempsey por nocaute no segundo round. https://www.youtube.com/watch? $\mathrm{v}=\mathrm{Ky}$ CgxRntVwg

7 O amplo levantamento de fontes jornalísticas elencado nesta pesquisa foi possibilitado pela Hemeroteca Digital disponibilizada aos usuários pela plataforma do Arquivo Digital da Biblioteca Nacional. Para saber mais sobre a Hemeroteca Digital acesse: $<$ http://bndigital.bn.gov.br/sobre-a-bndigital/>. 
principalmente, por dois motivos: primeiro pelo fato da intensa cobertura realizada pela imprensa escrita brasileira, considerando que os jornais, naquele período, se constituíam no principal meio de comunicação de massa do país. Segundo, pela dificuldade em localizar fontes documentais, tendo em vista que naquele período não existia no Brasil nenhuma instituição oficial que controlasse eventos desta natureza. Por vezes os próprios jornais assumiam a responsabilidade da organização e divulgação desse tipo de evento.

As fontes jornalísticas consistem em um importante recurso a quem se propõe trazer à luz fatos passados, no entanto alguns cuidados são necessários para escapar da armadilha de interpretar tais fontes como o passado registrado objetivamente. Conforme apontado por Luca (2011), questões como subjetividades, convicções políticas, interesses comerciais, entre outros influenciam de que maneira tal notícia será ou não veiculada por determinado periódico. Portanto não se pretende aqui estabelecer uma verdade histórica acerca das expectativas e repercussões acerca do confronto pugilístico envolvendo o brasileiro Benedicto dos Santos e o italiano Ermínio Spalla, mas sim uma representação a partir da perspectiva dos periódicos.

Pensando no jornal enquanto fonte, cabe destacar - tal como Tania Regina de Luca (2008) aponta - que a escrita historiográfica por meio da imprensa é relativamente recente e bastante próxima das transformações sofridas pela disciplina da História. Estas modificações se vinculam aos entrelaçamentos entre a escrita científica e a busca pela verdade. A busca de uma verdade preconizada pelas escolas ${ }^{8}$ vigentes nesse período (século XIX e início do $\mathrm{XX}$ ), bem como apoiada na vertente positivista, apontava para o uso de fontes marcadas pela objetividade, fidedignidade, neutralidade e credibilidade. Desse modo, estabelecia-se uma hierarquia qualitativa dos tipos de fontes a serem utilizadas, que deveriam prezar pela neutralidade até então compatível aos documentos oficiais. Fontes como jornais, literatura, cartas ou diários, que em comum trazem a característica de estarem cercados pelo interesse (políticos, culturais, de classe, etc.), compromisso (seja com a estética, seja com o editorial) e subjetividade, eram compreendidas como inadequadas para recuperação do passado - tendo em vista esse afastamento da fidedignidade (VIEIRA et. al. 1984). Ao jornal caberia, portanto, a função de registrar fragmentos do presente, documentado sob a égide de compromissos, paixões e impulsos, os quais ainda estavam sujeitos a distorções, subjetividades e mais fragmentação.

A partir da Nova História Cultural, a qual propunha novos objetos, problemas e abordagens diversas, o jornal passa a destacar-se como fonte plausível (ALVES; GUARNIERI, 2007). Porém, são imprescindíveis alguns procedimentos para que essa fonte tivesse o seu devido reconhecimento.

Já não se questionava o uso dos jornais por sua falta de objetividade atributo que, de fato, nenhum vestígio do passado pode ostentar -, antes se pretendia alertar para o uso instrumental e ingênuo que tomava os periódicos como meros receptáculos de informações a serem selecionadas, extraídas e utilizadas ao bel prazer do pesquisador (LUCA, 2008, p. 116).

Isto é, a autora alerta para as armadilhas da imprensa - que, por sinal, também se aplicam ao tratamento de outros tipos de fonte -, já que o pesquisador poderia ficar tentado a recorrer ao

8 Para uma discussão mais profunda sobre a concepção de História, sua relação com a verdade e suas escolas, ler: Keith Jenkins, em A História Repensada (2011), e Peter Burke, em A Escola dos Annales (1997). 
jornal para confirmar determinada tese, extraindo apenas os trechos que lhe interessam. Assim, os elementos a que se deve atentar, para o uso de fontes jornalísticas, extrapolam o nível da publicação, quais sejam: motivações para a decisão de dar publicidade a determinados fatos, em detrimento de outros; as formas e linguagem com que o discurso é publicado; o perfil da linha editorial do periódico; os interesses políticos e financeiros; o lugar social de inserção do periódico; os colaboradores; o público a que se direciona; as fontes de receita; e o cruzamento com outras fontes.

Com sentido de contextualizar a prática de boxe no Brasil naquele período, vale aqui ressaltar que esta modalidade de combate, além de não gozar de muita popularidade no país, era compreendida por parcela da imprensa escrita brasileira como uma prática violenta e incivilizada (LISE, 2014). Não eram raras as matérias que condenavam o excessivo grau de violência física permitido nessas disputas. Embora esta crítica fosse recorrente, algumas disputas desta modalidade atraiam aos teatros ${ }^{9}$ um público razoável, principalmente na cidade do Rio de Janeiro.

Na segunda década do século XX a maioria dos confrontos de boxe realizados no Brasil era protagonizada por pugilistas estrangeiros, geralmente, de qualidade técnica duvidosa. Eram lutadores com idade avançada em fim de carreira ou mesmo aqueles que não conseguiam se destacar em países onde a modalidade era mais desenvolvida. A consequência disso foi uma gradativa perda de interesse do público pelos eventos de boxe, tendo em vista a qualidade insatisfatória dos combates.

No entanto, este panorama é sensivelmente modificado pela presença de um brasileiro nessas disputas. José Floriano Peixoto, filho do ex-presidente Marechal Floriano Peixoto, disputou algumas lutas sagrando-se vencedor na maioria delas. A participação de José Floriano em confrontos de boxe era amplamente divulgada pelos periódicos cariocas, tal fato possivelmente tenha contribuído para melhorar a visibilidade do boxe no Brasil.

\section{Impressões e expectativas}

Spalla chegava ao continente sul-americano na condição de campeão, italiano e europeu, dos pesos pesados, embora alguns periódicos paulistanos publicassem matérias que questionavam a legitimidade destes títulos, "Spalla campeão europeu de todos os pesos?" (O COMBATE, 8 jul. 1923, p. 3). Tais reportagens alegavam que os verdadeiros campeões europeus eram Georges Carpentier ${ }^{10}$ e Joe Becket ${ }^{11}$ ou ainda Mc Tigue ${ }^{12}$. As críticas em relação

9 Ciente de não haver naquele período espaços específicos para a prática de esportes de combate, tais como o boxe, a luta romana e o jiu-jitsu, por exemplo, o empresário italiano Paschoal Segreto, dono de uma rede de teatros dedicados às classes mais populares do Rio de Janeiro, resolveu investir nesse tipo de espetáculo sediando diversos campeonatos e obtendo relativo êxito (LISE, 2014).

10 Embora tenha disputado algumas lutas na categoria de peso pesado, o francês Georges Carpentier era, segundo o site boxrec um peso meio pesado, tendo sido campeão europeu e mundial desta categoria no ano de 1919 (http://boxrec.com/ boxer/32006).

11 O peso pesado inglês Joe Beckett já havia se retirado dos ringues no ano de 1923.

12 Não foi possível identificar este lutador. 
à condição de Spalla foram prontamente contestadas pelo jornal diário Fanfulla ${ }^{13}$, o qual declarava que o lutador italiano era o legítimo campeão dos pesos pesados na Europa e que o articulista do periódico O Combate desconhecia o mundo do boxe. Os debates acerca do status de Spalla foram intensos e ganharam conotações nacionalistas e patrióticas, principalmente em relação ao jornal dos italianos.

Segundo as fontes elencadas para esta pesquisa, possivelmente o único compromisso pré-agendado de Spalla na América do Sul fosse o combate contra o pugilista argentino Firpo, pois ao fazer escala tanto na cidade do Rio de Janeiro quanto em Montevidéu declarou que se outras lutas não fossem marcadas ele retornaria rapidamente para a Itália para cumprir outros compromissos (CORREIO PAULISTANO, 31 jan. 1924, p. 2). Segundo o próprio Spalla em entrevista ao jornal carioca $A$ Noite, "A minha vinda à América do Sul foi decidida de um momento para o outro" (A NOITE, 26 jan. 1924, p.7).

A luta entre Spalla e Firpo, realizada no estádio de futebol pertencente ao Club Atlético River Plate na capital argentina, alcançou um público de mais de vinte mil pessoas. Este confronto causou relativa expectativa também no Brasil, primeiro pela reconhecida qualidade técnica dos dois pugilistas e segundo porque alguns jornais especulavam que o vencedor desta luta se credenciaria à disputa do título mundial dos pesos pesados contra o campeão Jack Dempsey. O jornal Correio Paulistano fez a cobertura desta disputa via telégrafo e publicou uma longa matéria na qual destacava a repercussão do combate, o qual foi acompanhado por centenas de apreciadores de boxe que lotavam a Praça Antônio Prado, onde eram divulgados os boletins com os principais lances da luta ${ }^{14}$. Com a derrota de Spalla por knock-out durante o décimo quarto round notou-se uma grande decepção dos simpatizantes de Spalla, em especial daqueles com descendência italiana (CORREIO PAULISTANO, 8 mar. 1924, p. 2).

Entretanto, alguns periódicos de Buenos Aires colocavam essa luta sob suspeição. Jornalistas argentinos que acompanharam o combate publicaram notas que repercutiram depois nos jornais brasileiros. O jornal O Paiz, diário de maior circulação na cidade do Rio de Janeiro, publicou pequena nota questionando: "Teria havido combinação prévia entre os contendores?" (O PAIZ, 9 mar. 1924, p. 2). O Correio Paulistano também manifestou certa desconfiança quanto a este confronto: "Como telegrafamos, causou má impressão a luta entre Firpo e Spalla, cujas atuações foram uma verdadeira desilusão. Acredita-se que o prolongamento dos rounds foi feito propositalmente. O público, no decorrer do jogo, protestou contra o modo pelo qual o mesmo vinha sendo executado" (CORREIO PAULISTANO, 9 mar. 1924, p. 2). Tais insinuações quanto à veracidade desta luta foram prontamente respondidas e justificadas por ambos os lutadores. Firpo alegou que desde a derrota contra Jack Dempsey, seis meses antes, sofria de dores agudas no braço esquerdo, tal fato o levou a tomar uma aspirina antes do combate contra Spalla, segundo o argentino, o medicamento além de não atenuar as dores no braço, que ficou quase inutilizado no decorrer da luta, ainda causou problemas de "dupla visão" (O PAIZ, 18 mar. 1924, p. 7). Spalla, por sua vez, argumentou que a longa viagem da Itália até Buenos Aires prejudicou sua condição física impossibilitando uma excelente performance.

13 Com tiragem diária de aproximadamente quinze mil exemplares, o jornal Fafulla, fundado em 1893 era considerado o principal órgão de imprensa italiana no Brasil, portanto, era pretensamente voltado aos oriundi ou descendentes de italianos (ARQUIVO PÚBLICO DO ESTADO DE SÃO PAULO, 2009). http://www.arquivoestado.sp.gov.br/imigracao/imprensa.php 14 A Praça Antonio Prado, localizada no centro da cidade de São Paulo, abrigava a sede do jornal Correio Paulistano. Os boletins de cada round da luta eram recebidos direto de Buenos Aires, via telegrafo, e eram publicados em murais expostos na praça. 
Logo após a derrota para o lutador argentino, Spalla propôs imediatamente uma revanche, possivelmente para desfazer a má impressão deixada pelos dois lutadores e os comentários a respeito de uma suposta manipulação da luta. Firpo por sua vez recusou o desafio de um novo confronto. Apesar destas circunstâncias, tiveram início as negociações com propósito de realizar uma luta entre o pugilista italiano e Benedicto dos Santos na cidade de São Paulo. Um empresário do ramo de loterias da capital paulistana ofereceu a Spalla a quantia de cem mil réis ${ }^{15}$ pelo confronto. Ermínio Spalla recusou a proposta tendo em vista uma repentina viagem para os Estados Unidos da América cujo objetivo estava relacionado com a negociação de uma disputa contra o norte-americano Gene Tuney ${ }^{16}$. No entanto, o lutador italiano se propôs a realizar, ao custo de dez mil liras, uma "demonstração pugilística" (CORREIO PAULISTANO, 13 abr. 1924, p. 1), descrita da seguinte maneira.

O campeão italiano não pode evidenciar os seus predicados ou méritos na escola do boxe. Limitou-se unicamente a defender-se de alguns socos que os três pugilistas, seus contendores desferiram, visando sempre o rosto daquele atleta. Depois, porém, uns quatro ou cinco diretos aplicados pelo boxeador visitante, davam a impressão que os seus adversários não poderiam, em uma luta real, oferecer resistência apreciável. Tudo isso não impressionou favoravelmente os espectadores que supunham presenciar uma exibição sensacional do violento esporte, sendo que assistiram a uma simples demonstração destituída de interesse (CORREIO PAULISTANO, 15 abr. 1924, p. 4).

O trecho acima se refere à noite de 14 de abril, na qual centenas de entusiastas lotaram o teatro Olympia, em São Paulo, na expectativa de assistir a um verdadeiro espetáculo de boxe. Todavia, como descreve o jornal, o que se passou foi uma mera apresentação de técnicas, destituídas de qualquer caráter competitivo. Esta situação decepcionou os presentes, os quais alegavam terem sido vítimas de uma impostura. Outro detalhe importante destacado na referida matéria faz alusão ao fato de que Spalla lutou seis rounds contra três lutadores brasileiros, Delunnay, Scaglio e Benedicto dos Santos e, segundo o jornal, nenhum deles seria capaz de colocá-lo em risco dada a enorme diferença técnica entre os brasileiros e o italiano. Ao final da matéria, o jornal relata que mesmo com a disparidade técnica entre os lutadores, Benedicto dos Santos havia desafiado Spalla para um confronto quando este retornasse dos Estados Unidos da América. Spalla aceitou o desafio prontamente.

No dia 17 de abril de 1924, o periódico carioca Jornal do Brasil anunciava em breve nota que Erminio Spalla esteve nas dependências da Empresa Matarazzo, onde assinou o contrato oficializando a disputa contra Benedicto dos Santos. Não foram divulgados os valores que os pugilistas receberiam ${ }^{17}$, mas a data e o local já estavam definidos. A luta aconteceria no dia 11 de maio no Parque Antarctica, estádio da equipe de futebol Palestra Itália. Nesse momento fica evidenciado o esforço dos ítalo-brasileiros para a realização deste combate, considerando que os principais interessados em promover a referida disputa tinham vínculos com a comunidade

15 Uma casa na região central da cidade de São Paulo custava aproximadamente vinte mil réis.

16 Gene Tunney se tornaria campeão mundial dos pesos pesados no ano de 1926 ao derrotar o então detentor do título, Jack Dempsey. Um ano depois esta luta se repetiria com outra vitória de Tunney.

17 Alguns periódicos publicaram que Spalla havia recusado a primeira proposta para receber 100 mil liras. Alguns periódicos afirmaram que Spalla havia assinado o contrato pelo valor de 300 mil liras. 
italiana $^{18}$

Após a confirmação oficial do confronto entre Spalla e dos Santos a imprensa escrita brasileira passou a cobrir amplamente os preparativos para a disputa. Dezenas de matérias foram dedicadas ao combate e é sensível a repentina mudança nos discursos dos jornais, que agora destacavam as qualidades de Benedicto dos Santos, colocando-o em condição de igualdade em relação ao italiano e negligenciando as disparidades técnicas anteriormente constatadas "Os dois valorosos competidores pisam o ringue da luta em iguais condições: nos treinos preparatórios ambos revelaram suas ótimas qualidades e excelentes recursos disponíveis, sendo assim difícil prever a quem a sorrirá a vitória" (CORREIO PAULISTANO, 11 mai. 1924, p. 6). Se em um momento anterior dos Santos era considerado inapto tecnicamente, pouco tempo depois ele se constituía no "hercúleo atleta patrício". Possivelmente esta mudança de discursos tivesse a intenção de promover o combate, que para alguns periódicos era considerado o maior evento pugilístico já realizado no Brasil.

Ao longo do mês que antecedeu a luta, a cobertura da imprensa brasileira se intensificou, todos os detalhes eram analisados, desde a preparação dos atletas em treinos abertos ao público nos teatros da cidade, entrevistas com os dois contendores, a adaptação do estádio de futebol do Palestra Itália para receber com conforto dezenas de milhares de espectadores, o destacamento de trezentos policiais para garantir a segurança durante o evento, a disponibilidade extra de transporte público para facilitar a ida ao estádio, os procedimentos adotados para a venda de ingressos, enfim todos os detalhes acerca desta luta foram retratados em vários jornais da cidade de São Paulo. O periódico Correio Paulistano descreveu a luta da seguinte maneira. "A maior e mais importante reunião pugilística até hoje realizada no Brasil. Três lutas preliminares e um sensacional encontro de fundo, cuja realização vem empolgando a atenção do público de norte a sul do país quiçá de todo continente" (CORREIO PAULISTANO, 10 mai. 1924, p. 8). $\mathrm{Na}$ semana que antecedeu a luta os cinemas da cidade de São Paulo estrearam a exibição do filme da luta entre Spalla e Firpo, e segundo o jornal $O$ Combate, cerca de treze mil pessoas assistiram a película em apenas uma semana (O COMBATE, 10 mai. 1924, p. 2).

A disputa pugilistica entre Spalla e dos Santos tomou grandiosa proporção e mobilizou a cidade de São Paulo. Mais de vinte mil ingressos foram vendidos com antecedência, um público excepcional para uma luta de boxe ${ }^{19}$. A organização foi exemplar, tanto do ponto de vista estrutural quanto da promoção do evento, que contou com o apoio e divulgação dos principais periódicos da capital paulistana. O jornal Correio Paulistano anunciava em um "boletim oficial de informações" que a empresa Bandeirantes transmitiria a luta, ao vivo, via rádio, para todas as capitais da América do Sul. Além disso, a Companhia Cinematográfica Independência-Omnia havia se disposto a realizar a filmagem do evento (CORREIO PAULISTANO, 11 mai. 1924 p. 4). Esta película é considerada como uma das primeiras longas

18 A família Matarazzo, considerada a mais rica do Brasil, era majoritariamente composta de ítalo-brasileiros que se estabeleceram como uma das principais potências industriais do estado de São Paulo. O clube de futebol Palestra Itália foi fundado em 1914 e era mantido com recursos oriundos dos descendentes italianos.

19 De acordo com o site do Instituto Brasileiro de Geografia e Estatística (IBGE) a população da cidade de São Paulo era de aproximadamente 580 mil habitantes (IBGE, 2015). 
metragens produzidas no país ${ }^{20}$.

Embora grande parte dos jornais da cidade de São Paulo tenha se manifestado favoravelmente em relação a esta disputa, havia, porém, periódicos e jornalistas que se colocavam de maneira contrária à realização desta. A revista semanal $A$ Vida Moderna era um desses periódicos. Em suas páginas não era raro encontrar matérias, assinadas pelo colunista João Garoa, que criticavam de forma contundente o evento de pugilismo... "Estamos voltando às épocas romanas em que se ia ao circo assistir monstruosidades por fabuloso preço, porque era moda e era bonito. Quem é que, raciocinando um pouco, um pouquinho só que seja, pode aplaudir esses tripúdios, essas brutalidades, esses bacanais do murro?" (GARÔA, 11 abr. 1924, p. 9). Na longa crônica, aqui editada, o colunista compara as lutas de boxe com as práticas gladiatórias romanas; mas em outra coluna vai mais longe, afirmando que os entusiastas do boxe não passam de "microcéfalos religiosos do muque", e por fim classifica Erminio Spalla como "[...] uma pessoa obtusa e emissário da brutalidade humana".

Essas críticas não eram apenas vozes isoladas, como já ressaltado anteriormente, matérias com esse teor não eram raras. No entanto esses editoriais criticando as disputas pugilísticas apontam para um tensionamento na própria imprensa escrita brasileira a respeito da qualidade do boxe enquanto esporte moderno e com características civilizatórias (ELIAS; DUNNING, 1992). Vale aqui ressaltar que essas tensões envolvendo os esportes de combate, em especial o boxe, já se faziam presentes nos periódicos nacionais desde a virada do século XIX, mas a repercussão do confronto entre Spalla e Benedicto dos Santos fez com que esse debate fosse retomado de forma mais intensa.

A luta e suas repercussões

Imagem 01 - Pugilismo. Fonte: A Vida Moderna, 22 mai. 1924, p.16.

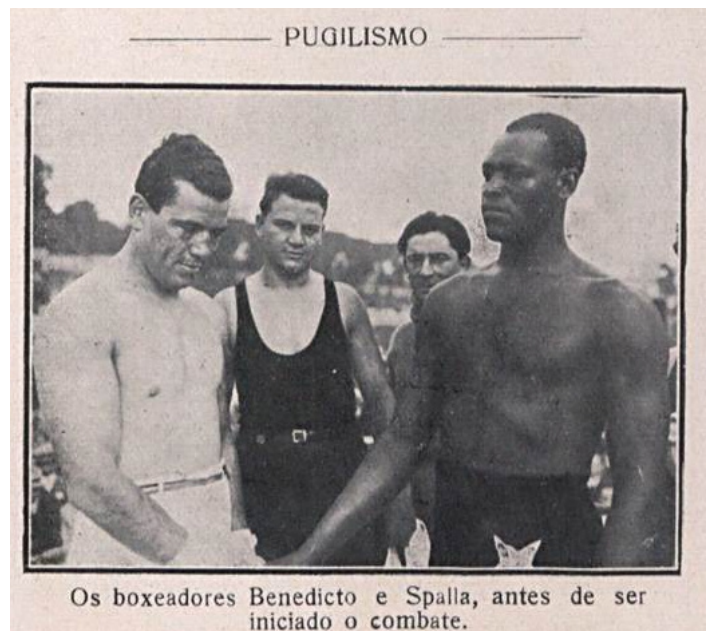

20 Segundo o site da Cinemateca Brasileira, instituição vinculada ao Ministério da Cultura, o documentário da luta entre Spalla e dos Santos foi gravado em filme de $35 \mathrm{~mm}$, dezesseis quadros por segundo, sem som, em preto e branco e possui aproximadamente uma hora de duração e é dividido em seis partes. Embora a Cinemateca tenha a ficha desta película, a mesma encontra-se desaparecida (CINEMATECA. GOV.BR, 2015). 
O confronto teve início às 16 horas do dia 11 de maio de 1924 e, segundo o jornal $A$ Rua, estiveram presentes no estádio do Palestra Itália aproximadamente vinte mil pessoas, das quais grande parte tinha ascendência italiana e simpatizava com seu conterrâneo; a outra parte (sem vínculo com a Itália), por sua vez, ansiava por uma vitória do lutador brasileiro. O jornal carioca Correio da Manhã descreveu da seguinte maneira o evento: "Não há exemplo de tal acontecimento, nem mesmo o mais sensacional encontro de futebol já realizado nos campos paulistas alcançou este interesse estupendo" (CORREIO DA MANH $\tilde{A}, 13$ mai. 1924, p. 3). O confronto estava programado para doze rounds de três minutos de duração por um minuto de descanso e os lutadores usaram luvas de seis onças, própria para lutas de pesos pesados, e o confronto esteve de acordo com o regulamento internacional de boxe.

\section{Imagem 02 - Pugilismo. Fonte: A Vida Moderna -22 mai. 1924, p. 27}

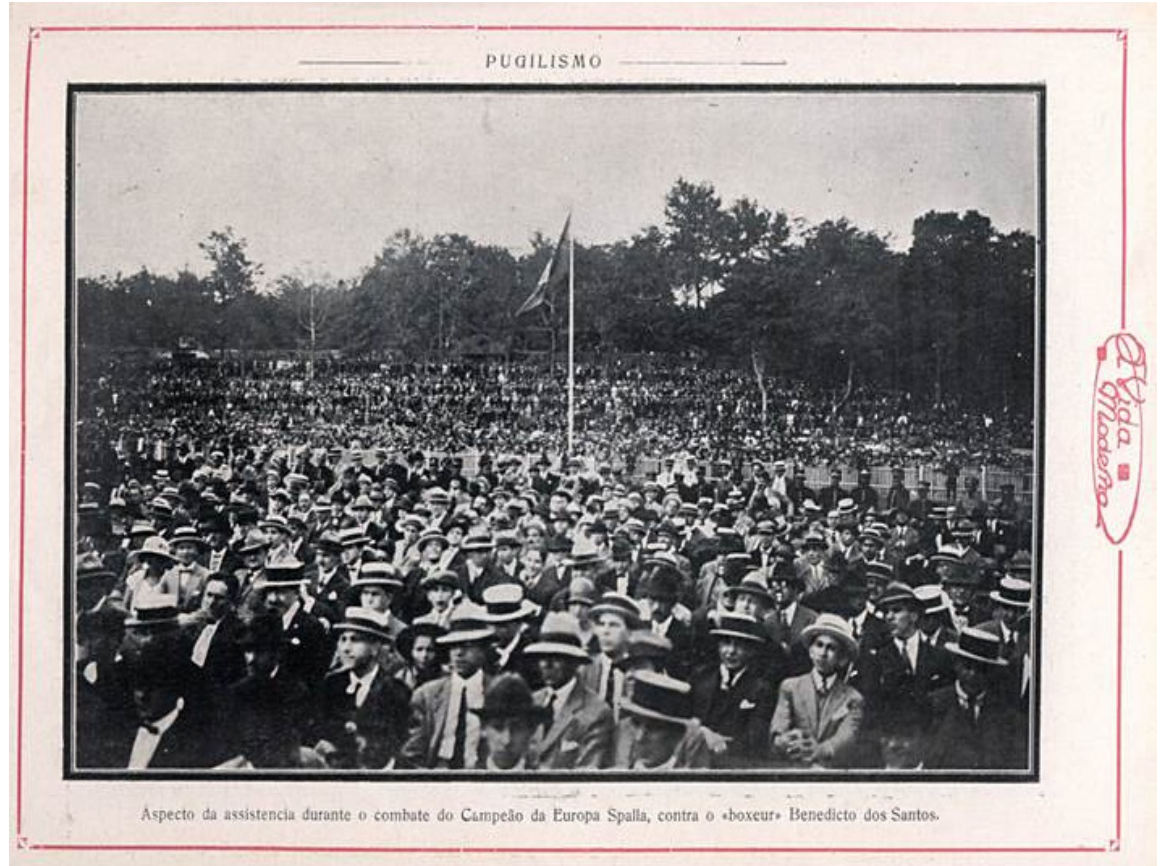

No dia 12 de maio o jornal Correio Paulistano dedicou uma grande matéria de capa intitulada "A denodada resistência do jogador brasileiro", a qual descreveu a luta round a round. Ao longo desta reportagem o periódico destacou a supremacia de Spalla sobre dos Santos em quase toda luta, exceto no quinto e sétimo round, nos quais o lutador brasileiro dominou as principais ações de ataque colocando em risco o pugilista italiano. Porém no nono round Spalla impõe a Benedicto dos Santos primeiramente um knockdown para logo seguida nocauteá-lo definitivamente (CORREIO PAULISTANO, 12 mai. 1924, p.1). 
Imagem 03 - O pugilismo em São Paulo. Fonte: A Cigarra, 1 mai. 1924, p.41.
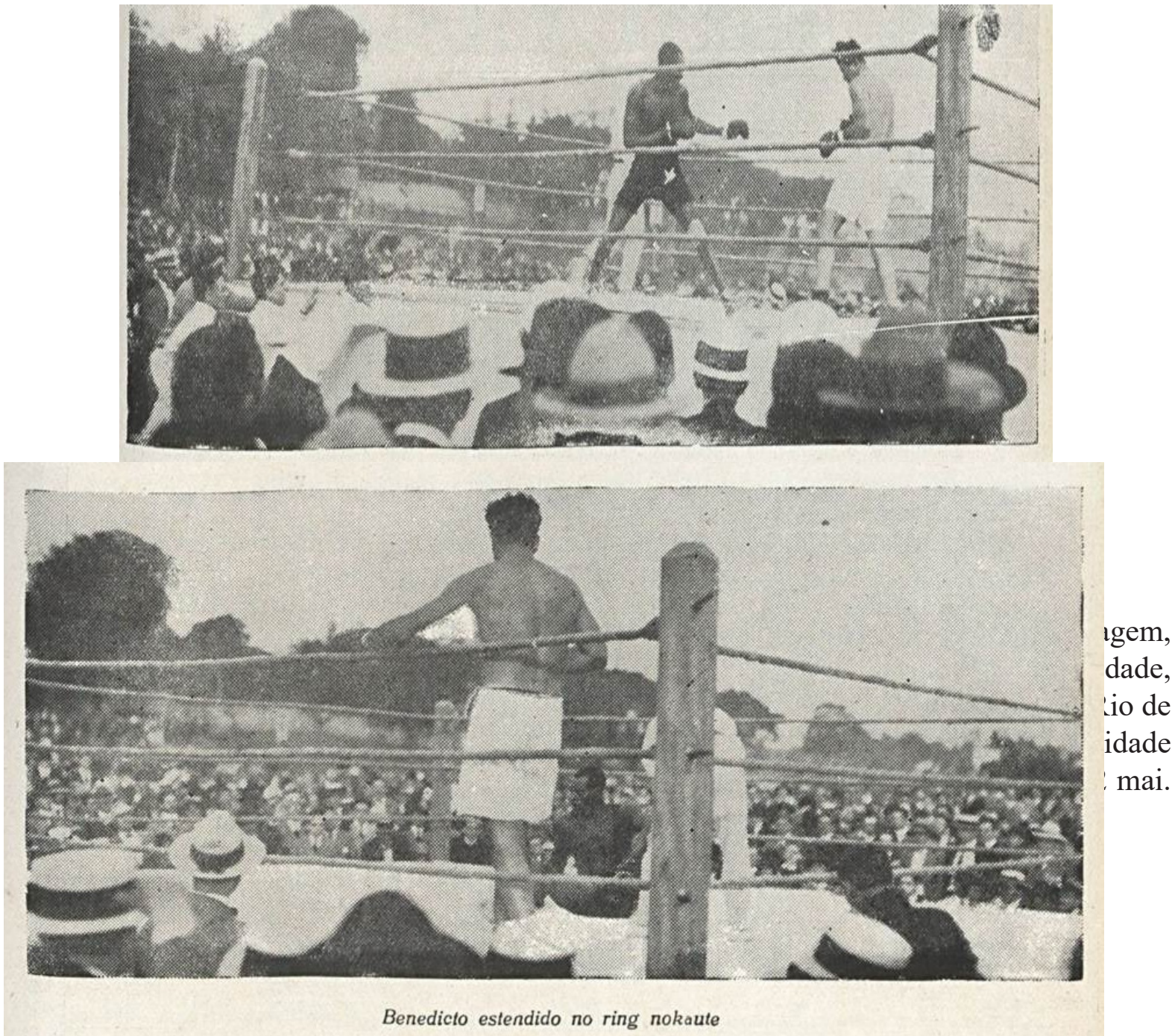

Se por um lado o periódico Correio Paulistano atribuiu a vitória de Spalla à sua superioridade técnica, por outro, o jornal $A$ Rua entendeu que o êxito do italiano se deu por conta de sua excepcional condição física. Ambos os periódicos acentuavam que o evento pugilístico realizado na cidade de São Paulo havia sido um sucesso e que este combate marcaria uma nova fase para o boxe no Brasil. Os elogios à qualidade técnica de Spalla e à resistência de dos Santos, somados à grande aclamação popular aos dois lutadores, reafirmam o caráter positivo deste evento. No entanto, um fato lamentável ensejaria outros discursos e sentidos dados a este confronto.

Na edição do dia 13 de maio de 1924, dois dias após a luta, o jornal Correio Paulistano informava, em longa coluna, que Benedicto dos Santos havia sido internado no hospital Alemão, na cidade de São Paulo, em estado grave. De acordo com o primeiro boletim médico 
Bendicto apresentava um quadro de hemiplegia no lado esquerdo ${ }^{21}$, sintoma de uma lesão no lado direito do cérebro, identificada pela equipe médica como uma hemorragia cerebral traumática. A partir deste incidente, a maioria dos jornais que dias antes realizavam a cobertura do "maior evento pugilístico da cidade de São Paulo" agora noticiava o "angustiante estado de saúde do lutador brasileiro". Spalla antes de embarcar para os Estados Unidos da América, com objetivo de iniciar sua preparação para a luta contra Gene Tuney, visitou o hospital onde Benedicto dos Santos estava internado. Impedido de falar pessoalmente com o pugilista brasileiro, Spalla escreveu em um breve bilhete "Sigo esta noite para Nova Iorque. Sinto não poder cumprimentar-te. Desejo-te um imediato e completo restabelecimento. Abraça-te afetuosamente Spalla" (CORREIO PAULISTANO, 14 mai. 1924, p. 2).

Os discursos da imprensa escrita brasileira novamente começam a se modificar de maneira sensível. Alguns periódicos começam a enfatizar a enorme disparidade técnica em favor de Spalla. Se em um período imediatamente anterior, os jornais colocavam os contendores em condições de igualdade, agora com o problema clínico de dos Santos as desigualdades técnicas passaram a ganhar destaque. Vários periódicos tanto da cidade de São Paulo quanto do Rio de Janeiro ressaltavam este disparate. O jornal carioca $O$ Paiz publicou em uma coluna o seguinte comentário sobre dos Santos. "Ademais, pouco acostumado a lutas como a que sustentou, não tendo o corpo habituado a receber os golpes que recebeu - pois que seu tempo de jogo é muito pequeno para que ele tenha formada sua constituição pugilística - sentiu-se bastante (O PAIZ, 15 mai. 1924, p. 9).

Antes de embarcar definitivamente para a América do Norte, o pugilista italiano, fazendo parada na cidade do Rio de Janeiro, concedeu uma entrevista ao jornal O Imparcial. Em uma longa matéria de capa, Spalla discorre sobre a luta contra dos Santos. Perguntado sobre as impressões a respeito do combate, Spalla comentou que a falta de experiência do lutador brasileiro foi decisiva; argumentou ainda que para se tornar um grande lutador dos Santos deveria enfrentar lutadores de segunda linha para depois bater-se com atletas mais qualificados. De certa maneira essa fala do pugilista italiano estava coadunada ao novo discurso da imprensa escrita brasileira. Benedicto dos Santos não estava preparado para enfrentar um lutador com a categoria de Spalla. Além disso, perguntado sobre o estado de saúde do brasileiro, Ermínio Spala minimizou a gravidade da condição clínica de dos Santos, afirmando que situação como esta já havia ocorrido em outro combate, no qual o seu adversário apresentou os mesmos sintomas de paralisia lateral parcial, mas que com pouco tempo de repouso absoluto recuperouse completamente (O IMPARCIAL, 15 mai. 1924, p. 1).

O discurso de Spalla acerca do estado de saúde de Benedicto dos Santos era, de certa maneira, compartilhado pela junta médica que acompanhava o restabelecimento do lutador brasileiro. Os primeiros boletins médicos afirmavam que o quadro clínico era grave, mas ao longo da semana que sucedeu o combate havia se verificado uma evidente melhora da paralisia parcial que acometeu dos Santos. A rápida evolução do estado de saúde ensejou o prognóstico de que a recuperação completa se daria em poucos dias. No entanto, esta suposição não se confirmou e passado mais de um mês do início do tratamento o quadro clínico havia permanecido inalterado.

O jornal Correio Paulistano e também o periódico O Paiz publicaram notas a respeito

21 Paralisia total ou parcial da metade lateral do corpo. 
da então situação financeira do lutador brasileiro (CORREIO PAULISTANO, 26 jun. 1924, p. 5), (O PAIZ, 27 jun. 1924, p. 9). Segundo tais notícias, dos Santos, que tinha recebido trinta mil réis como pagamento da luta, já havia gasto mais de quinze mil réis por conta das despesas hospitalares, e ainda, o resto do dinheiro que levava consigo foi roubado por um enfermeiro, que logo depois do delito empreendeu fuga e o dinheiro não pôde ser recuperado. Dos Santos recebeu alta do Hospital Alemão após quase três meses de internamento, e segundo os médicos o quadro de paralisia parcial era definitivo. As despesas com o tratamento foram pagas por amigos do lutador brasileiro.

Após tomar ciência das condições físicas e financeiras de dos Santos, a Companhia Cinematográfica Independência-Omnia, a qual pertencia à família Matarazzo, com a anuência de Spalla, de maneira generosa, dedicou parte dos lucros provenientes da comercialização do filme da luta em benefício do lutador brasileiro. Tal ação altruísta propiciou a dos Santos uma sensível melhora de sua condição financeira.

Em 16 maio de 1924 uma extensa reportagem foi reproduzida pelo jornal Correio Paulistano. A coluna que ocupava o espaço ao lado da entrevista de Spalla, intitulada "Morra o box", era assinada por Helios ${ }^{22}$. Com requintes literários, a longa crônica condenava de forma contundente a prática do boxe, considerando esta modalidade como "[...] uma aberração humana praticada por peludos bárbaros e antropófagos". Helios compreendia o boxe como...

Essa arte de matar em público, entre aplausos e entre apostas, essa sanguinária ciência de expor um corpo nu e torturado à vista facinorosa de milhares de neo-bárbaros, que uivam a cada golpe, que ovacionam o fio de sangue que escorre da fenda aberta no beiço, o tombo frouxo do corpo em síncope, dá-me uma íntima vergonha, vendo que sem nenhuma razão, usurpamos a Linneu a denominação de "homo sapiens" e aos sociólogos a de "seres civilizados" (HELIOS, 16 mai. 1924, p. 3).

Embora o colunista Helios não se referisse diretamente ao confronto entre Spalla e Benedicto dos Santos ficava subentendido que se referia a esta disputa. Novamente, tornase possível perceber uma contraposição entre a prática do boxe e elementos de civilidade. $\mathrm{O}$ autor se utiliza de uma série de figuras de linguagem que enfatizam a violência presente nessas disputas, cuja prática, segundo ele, afastava os seres humanos da ideia de humanidade. As duas matérias, lado a lado, ilustravam de maneira explícita os tensionamentos presentes na imprensa escrita brasileira acerca dos esportes de combate, entendido por uns como esporte moderno e civilizado, no qual a regulamentação efetiva controlava os níveis de violência e para outros como uma prática bárbara, cuja brutalidade é o único objetivo.

Com a ida de Spalla para os Estados Unidos da América, a cobertura da imprensa escrita brasileira ficou centrada no precário estado de saúde de dos Santos e nas severas críticas à pratica de boxe no Brasil, em especial na cidade de São Paulo. O colunista do Correio Paulistano Helios, um dos mais contundentes críticos do boxe publica sistemáticas crônicas, nas quais objetivava censurar tal modalidade esportiva. Em um destes textos, Helios acentuou que, em parceria com um grupo formado por médicos e juristas, havia apresentado aos órgãos

22 Helios era o pseudônimo utilizado pelo literato Menotti del Picchia, um dos idealizadores da semana de arte moderna de 1922 e também descendente de italiano. 
competentes uma moção solicitando a proibição da prática do boxe na cidade paulistana. Pouco tempo depois, em um decreto assinado pelo governador do estado de São Paulo, estaria suspensa a prática de boxe até que se instituísse uma comissão que regulamentasse e organizasse tais confrontos. "Em São Paulo vão acaloradas as discussões em torno da recente resolução do governo, proibindo a prática do boxe" (A RUA, 25 jun. 1924).

A consequência desta resolução suspendendo as lutas de boxe em São Paulo ensejou a constituição de uma delegação que intentava legalizar e regulamentar tal prática competitiva na cidade. No dia 28 de junho de 1924, pouco mais de um mês após o confronto entre Spalla e Benedicto dos Santos, o Correio Paulistano publicou uma matéria na qual foi divulgada a lista de nomes dos integrantes de uma comissão cujo objetivo era elaborar um estatuto que regulamentasse o boxe em São Paulo. Com sentido de legitimar a criação desta comissão perante aqueles que discursavam de maneira contrária a prática de boxe, voltaram à tona os discursos acerca da desigualdade técnica entre Spalla e o boxeador brasileiro. "Não teria havido este encontro, porque a comissão não permitiria que um campeão absoluto de Box da Europa, do valor de Spalla, se batesse com um principiante, que só tinha a seu favor uma grande coragem e uma força hercúlea" (CORREIO PAULISTANO, 28 jun. 1924, p. 5). Nesta mesma edição era noticiado a derrota de Ermínio Spalla para Gene Tunney, por nocaute no sétimo round, na cidade de Nova Iorque.

Vários anos depois, no final de dezembro de 1933, o periódico O Jornal, publica em suas páginas uma breve nota dando conta da chegada de Ermínio Spalla ao Brasil. Segundo esta matéria, Spalla chegava ao país na condição de contratado pelo governo do estado de São Paulo para dirigir uma escola de pugilismo e ginástica (O JORNAL, 17 dez. 1933, p. 16). Já em junho de 1934 é anunciado pelo periódico O Paiz a chegada de Esmeralda Spalla, esposa de Erminio Spalla, e seus filhos, a família fixou residência na capital paulista. No ano de 1934 o pugilista italiano, já destituído do título de campeão europeu, disputou três lutas: vitória sobre Marcel Nilles por nocaute técnico, vitória sobre Laverne Baxter por nocaute, e vitória sobre Wladek Zbyszko por desclassificação. Após essa luta, Spalla anunciou a sua aposentadoria dos ringues. Nenhum desses combates teve grande repercussão na imprensa escrita brasileira.

\section{Considerações finais}

O confronto entre Erminio Spalla e Benedicto dos Santos, no ano de 1924, na cidade de São Paulo, certamente não foi a luta mais importante que o lutador italiano realizou em sua visita às Américas. Neste tour, Spalla realizou um total de cinco lutas: além do confronto no Brasil, derrota contra Firpo na Argentina, derrota contra Tunney e outras duas lutas de menor expressão nas quais Spalla saiu vitorioso, essas últimas nos Estados Unidos da América. No entanto, a importância que os periódicos brasileiros deram ao combate contra dos Santos, estimulou o interesse da população e gerou muitas expectativas. Enfim, as repercussões dos diversos discursos proferidos pela imprensa escrita brasileira fizeram desta luta o maior evento pugilístico até então realizado no país. 
Este confronto idealizado e organizado por descendentes italianos, realizado no estádio Palestra Itália, foi uma espécie de celebração da imigração italiana no Brasil. Além disso, havia por parte dos organizadores a intenção de popularizar o boxe no país, e um evento desta magnitude seria de fundamental importância. Porém, o internamento de Benedicto dos Santos, ocasionado pelos golpes de Spalla, deu a esta luta outros sentidos.

De volta à América do Sul, no ano de 1926, Spalla, realizou sua segunda luta contra o argentino Luiz Angel Firpo e novamente o lutador italiano foi derrotado, desta feita pela pontuação dos jurados. Após este revés Spalla se encaminhou para o Brasil e ciente dos problemas de saúde e das dificuldades financeiras enfrentadas por dos Santos, tomou a iniciativa de realizar um festival de boxe no qual, parte dos lucros obtidos por tal evento foi destinado ao lutador brasileiro. Este festival foi realizado no Theatro Braz Polytheama e teve como luta principal o confronto entre o próprio Ermínio Spalla e Joe Boykin e ainda mais três lutas preliminares. Todas as lutas tiveram a supervisão da Comissão de Box de São Paulo, lembrando que tal comissão se instituiu a partir da luta entre Spalla e dos Santos. O jornal Correio Paulistano anunciou a luta da seguinte maneira:

Realiza-se, hoje, á noite, no Braz Polytheama, a esperada reunião de Box, organizada com um bom programa. O combate principal, travar-se-á entre Spalla, campeão europeu de todos os pesos e Boykin, pugilista norteamericano, ex-treinador de Firpo. [...] O interesse que se nota em nossos círculos esportivos por esta noitada pugilística, é dos maiores. Todos desejam apreciar a técnica apregoada do pugilista negro, da América frente ao magnífico "máximo italiano". [...] As bolsas de Spalla, 19 contos, e de Boykin 10 contos já foram depositados. Benedicto dos Santos, o esmurrador patrício, será beneficiado, cabendo-lhe a importância de 6 contos mais os direitos de exploração do filme que será tirado do encontro. (CORREIO PAULISTANO, 21 abr. 1926, p. 6).

Segundo esta nota, aqui editada, o empreendimento organizado por Spalla ganhou a simpatia da imprensa escrita brasileira a qual participou de forma ativa promovendo sistematicamente o festival. $\mathrm{O}$ interesse dos periódicos se deu por principalmente por dois motivos; primeiro pela qualidade técnica dos protagonistas, tendo em vista que Spalla ainda era o campeão europeu dos pesos pesados e Joe Boykin era assistente técnico de Angel Firpo. E segundo, pela atitude altruísta de Spalla em benefício a Benedicto dos Santos, este último muito apreciado pelo público brasileiro. O evento organizado por Spalla obteve grande sucesso, o Theatro Bráz Polytheama ficou lotado para assistir o empate entre o lutador italiano e Boykin. O jornal Il Pasquino publicou a seguinte notícia sobre o evento organizado por Spalla:

Acrescenta-se, ainda, que o gigantesco filho da terra de Mussolini, em um gesto de grande generosidade, atendendo ao estado em que ainda se encontra Dictão, abrirá mão de toda receita líquida em favor do campeão do Brasil. Se isso acontecer, um grande gesto do formidável Spalla - gesto aliás, comum e infalível, nesse grande povo que é o povo italiano (IL PASQUINO COLONALE, 16 jan. 1926, p.15).

e ainda... 
Respiramos e... Anotamos... Porém, nos parece que a justiça deveria ter sido feita mais cedo. Spalla é um ótimo filho da pátria, um justo combatente e podemos garantir que ninguém sofreu tanto quanto ele com o doloroso “caso" Benedicto23 (IL PASQUINO COLONIALE, 16 jan. 1926, p.15).

Por fim, vale ainda ressaltar as significativas mudanças dos discursos dos periódicos que cobriram o evento. Os discursos acerca deste combate não se encerraram com o término da luta, então, foi possível notar neste estudo que as construções discursivas acerca de um mesmo fato se alteram de acordo com as perspectivas do presente, ou seja, o passado é reformulado constantemente, para que estas construções discursivas possam fazer sentido no tempo presente. Daí a necessidade de rigores metodológicos, de contextualizar e de relativizar as fontes do tipo jornalísticas, para que elas não se tornem um relato absolutamente factual do passado. E embora os discursos da imprensa brasileira sofressem uma série de modificações ao longo dos anos uma fala de Benedicto pode ser muito esclarecedora "Quem fala mal do Spalla não sabe o que diz... o Spalla é um camaradão e um verdadeiro amigo" (IL PASCHINO COLONIALE, 16 jan. 1926, p.15).

\section{REFERENCIAS}

A CIGARRA. O pugilismo em São Paulo. São Paulo: A Cigarra, 01 mai. 1924A, p.41.

A CIGARRA. O pugilismo em São Paulo. São Paulo: A Cigarra, 01 mai. 1924B, p.41.

A NOITE. Spalla vai enfrentar Firpo. Rio de Janeiro: A Noite, 26 jan. 1924, p.7.

A RUA. Proibir ou regulamentar a "nobre arte"? Rio de Janeiro: A rua, 25 jun. 1924, p.2.

. Spalla vence com grande dificuldade Benedicto. Rio de Janeiro: A Rua, 12 mai. 1924, p.2.

A VIDA MODERNA. Pugilismo. São Paulo: A Vida Moderna, 22 mai. 1924, p.16.

A VIDA MODERNA. Pugilismo. São Paulo: A Vida Moderna, 22 mai. 1924, p.27.

ARQUIVO PÚBLICO DO ESTADO DE SÃO PAULO. Imigração em São Paulo. 2009). Disponível em: <http:// www.arquivoestado.sp.gov.br/imigracao/imprensa.php>. Acesso em: 22 nov. 2015.

23 Respiriamo e ... prendiamo nota... Peró ci sembrache giustizia avrebbe dovuto essere stata fatta anche prima... Spalla é un ottimo figliolone, um correttissimo combatente e possiamo garantire che nessuno soffri' tanto com'egli sofferseper Il dolloroso “caso" Benedicto (IL PASQUINO COLONIALE, 16 jan. 1926, p.15). No texto em tradução livre. 
BOXREC. Georges Carpentier. Disponível em: <http://boxrec.com/boxer/10604>. Acesso em 16 dez. 2015. . Joe Beckett. Disponível em: <http://boxrec.com/boxer/32006>. Acesso em 16 dez. 2015.

CINEMATECABRASILEIRA. Spalla versus Benedicto. Disponível em: < http://www.cinemateca.gov.br/cgi-bin/ wxis.exe/iah/?IsisScript=iah/iah.xis\&base=FILMOGRAFIA\&exprSearch=Spalla\&nextAction=lnk\&lang=p $>$. Acesso em: 09 nov. 2015.

CORREIO DA MANHÃ. No mundo do Box. Rio de Janeiro: Correio da Manhã, 13 mai. 1924, p.3.

CORREIO PAULISTANO. A denodada resistência do jogador brasileiro. São Paulo: Correio Paulistano, 12 mai. 1924, p.1.

. A luta Firpo - Spalla. São Paulo: Correio Paulistano, 9 mar. 1924, p.2.

Box - Uma reunião a Sociedade Hípica. São Paulo: Correio Paulistano, 28 jun. 1924, p.5.

. Box. São Paulo: Correio Paulistano, 13 abr. 1924, p.1.

Box. São Paulo: Correio Paulistano, 21 abr. 1926, p. 6.

Dois pugilistas em viagem. São Paulo: Correio Paulistano, 27 jan. 1924, p.1.

O boxeur Benedicto. São Paulo: Correio Paulistano, 14 mai. 1924, p.2.

O campeão do soco. São Paulo: Correio Paulistano, 8 mar. 1924, p.2.

O pugilista Spalla. São Paulo: Correio Paulistano, 31 jan. 1924, p.2.

Pugilismo Spalla vs. Benedicto. São Paulo: Correio Paulistano, 10 mai. 1924, p.8.

. Pugilismo. São Paulo: Correio Paulistano, 15 abr. 1924, p.4.

Spalla vs. Benedicto. São Paulo: Correio Paulistano, 11 mai. 1924, p.6.

. Um gesto generoso. São Paulo: Correio Paulistano, 26 jun. 1924, p.5.

. Spalla vs. Benedicto. São Paulo: Correio Paulistano, 11 mai. 1924, p.4.

ELIAS, Norbert; DUNNING, Eric. A Busca da Excitação. Rio de Janeiro: Difel, 1992. 
ENCICLOPÉDiA ITAÚ CULTURAL. Menotti Del Picchia. Disponível em: < http://enciclopedia.itaucultural. org.br/pessoa2856/menotti-del-picchia>. Acesso em: 02 dez. 2015.

GARÔA, João. O “trote” na Academia. São Paulo: A Vida Moderna, 11 abr. 1924, p. 9.

HELIOS. Morra o box. São Paulo: Correio Paulistano, 16 mai, 1924, p.3.

IL PASQUINO COLONIALE. O Minio! Gonfiati! São Paulo: Il Paschino Coloniale, 16 jan. 1926, p.15.

INSTITUTO BRASILEIRO DE GEOGRAFIA E ESTATÍSTICA. História demográfica do município de São Paulo. Disponível em: < http://smdu.prefeitura.sp.gov.br/historico_demografico/tabelas/pop_brasil.php>. Acesso em: 17 nov. 2015.

LISE, Riqueldi Straub. Entre diretos, ceintures avant, chaves de braço e rabos de arraia: os primórdios dos combates intermodalidades na cidade do Rio de Janeiro (1909-1929). Dissertação (Mestrado em Educação Física) - Universidade Federal do Paraná, 2014.

LUCA, Tania Regina de. História dos, nos e por meio dos periódicos. In: PINSKY, Carla Bassanezi (Org.). Fontes Históricas. São Paulo: Contexto, 2011, p. 111-153.

O COMBATE. Colombo, Phenix e Colombinho. São Paulo: O Combate, 10 mai. 1924, p.2. Spalla campeão europeu de todos os pesos? São Paulo: O Combate, 8 jun. 1923, p.3.

O IMPARCIAL. Os campeões do murro. Rio de Janeiro: O Imparcial, 15 mai. 1924, p.1.

O JORNAL. Erminio Spalla está em viagem para o Brasil. Rio de Janeiro: O Jornal, 17 dez. 1933, p.16.

O PAIZ. Box - Firpo x Spalla. Rio de Janeiro: O Paiz, 9 mar. 1924, p.2. Box. Rio de Janeiro: O Paiz, 18 mar. 1924, p. 7. Box. Rio de Janeiro: O Paiz, 27 jun. 1924, p. 9. O estado de Benedicto. Rio de Janeiro: O Paiz: 15 mai. 1924, p.9.

YOUTUBE. Jack Dempsey vs Luis Firpo. Disponível em: <https://www.youtube.com/watch?v=eoSEEXIe6Gg>. Acesso em: 15 dez. 2015.

RECEBIDO EM: 31/03/2020 APROVADO EM: 07/05/2020 